\title{
AS UTOPIAS DA EDUCAÇÃO MÉDICA
}

Toda revolução autêntica é precedida por um pensamento utópico. As utopias estiveram presentes na revolução francesa, como na revolução marxista, para citar apenas as que mais influência tiveram no mundo ocidental moderno. A própria ideologia liberal pode ser utópica, quando pretende mudar a realidade.

Em outras palavras: "O $\mathrm{O}$ que não é, mas que se deseja que possa vir a ser caracteriza a utopia". Há, assim, diversas formas de utopia.

Atrás da imaginação utópica, para que ela seja legítima, existe sempre uma força criadora de extraordinário poder. Mas é evidente que a utopia é contraditória por natureza, desde que se opõe à realidade que pretende mudar. E essencialmente transformadora, e só assim pode ser entendida. Entrando em conflito com a realidade, ela questiona - e questionañdo o faz em base dialética - aceitando que. . . "o desenvolvimento das coisas e dos fenômenos é provocado pelas suas contradições internas" e que. .." a interdependência e a luta dos aspectos contraditórios que thes são próprios deterrininam a sua vida e animam o seu desenvolvimento."

$E$ evidente que os participantes da reunião sobre Integração Docente-Assistencial, de iniciativa da ABEM, acontecida nos dias 16 e 17 de dezembro último, na Faculdade de Saúde Pública da Universidade de São Paulo, não estavam ali para discutir a educação médica sob o prisma de utopias messiânicas, visionárias, ou ucrônicas. Ali estavam porque acreditavam que a imaginação utópica não é um meio de fuga face à cruel realidade. Tâo pouco ali estavam empenhados em disputas diletantes ou acadêmicas. Ali estavam, sim, porque acreditavam que a utopia é a única força capaz de transformar a imaginaçáo em algo de concreto. Ali estavam os que acreditam na transformação da educação médica, compreendendo que os deveres da Universidade para com a sociedade, da qual faz parte, exige outra visão da educacão. $O$ objetivo finalístico da educação médica passa a ser definido em termos de seus compromissos com a comunidade, visando, em conseqüência, à melhoria de seus níveis de saúde e bem-estar.

Concordaram os participantes, presentes da reunião, em vários e importantes pontos. Debateram-se aspectos político-institucionais, organizacionais e operacionais. A experiência dos últimos dois decênios foi analisada, tendo sido o modelo instituído na Universidade de Brasília, em 1966, considerado como o primeiro e decisivo marco referencial de integração entre docência e serviços no país.

Instituições como a Fundação Kellogg, a FEPAFEM, a Organização Pan-Americana da Saúde e a Associação Brasileira de Educação Médica contribuíram de modo significativo para - desenvolvimento de projetos de integração docente-assistencial. A validade desses projetos, como de micro-modelos, foi discutida, concordando-se com a sua importância no processo de desenvolvimento da integração docente-assistencial, particularmente no melhoramento do conhecimento, no reforço de ordem conceitual, no desenvolvimento de know-how apropriado e no treinamento de pessoal. Entretanto, esses micromodelos foram incapazes de influir substancialmente nas pretendidas mudanças na educação médica e nos serviços.

Salientaram ainda os participantes a importância de leis, portarias, documentos e pareceres produzidos por órgãos governamentais (MS, MPAS, MEC) em apoio ao desenvolvimento de programas integrados docência/serviços, mencionando-se em particular os opúsculos "Integraç̃̃o Docente-Assistencial" e "Relatório do Gru- 
po Interministerial de Recursos Humanos", editados pela SESU/MEC, em 1981, e o recente Parecer emitido sobre o assunto pelo Conselho Federal de Educação.

Outro aspecto de extrema importância, com o qual concordaram os participantes, foi o de que as mudanças qualitativas da educaçăo médica (de modo mais abrangente, das ciências da saúde) não poderiam ser realizadas sem mudanças equivalentes no setor de saúde. Por este motivo rejubilaram-se, saudando e se congratulando com o Presidente do INAMPS e seus colaboradores, pela adoção do novo plano de saúde da Previdência que vem se constituir no primeiro passo efetivo dè mudança na atenção à saúde no país.

Por todos esses motivos concordaram os participantes que somente através de novos modelos educacionais da universidade brasileira, montados sobre a nova realidade a ser criada com a implantação do modelo previdenciário (CONASP), aliada a uma efetiva, concreta e democrática forma de participação comunitária, poderemos chegar a formalizar a utopia da educação médica que, uma vez institucionalizada, propiciará o desenvolvimento de novas utopias em permanente processo de renovação e mudança.

As discussões, mantidas no mais elevado nível de cordialidade, fizeram dessa reunião um marco decisivo da educação médica no país. Os micro-modelos de integração docente-assistencial devem ser transformados em macromodelos, envolvendo, de um lado, o setor de formação de recursos humanos e, de outro, o setor saúde em todos os seus níveis. Assim, seriam constituídos, através de instrumentos legais a definir, programas extensos de. integraç̃o serviços/docência.
Os que estavam na reunião - muitos com relevante folha de serviços na luta constante e de muitos anos - ali estavam porque acreditavam na necessidade de uma mudança estrutural da educação médica e do sistema de prestação de serviços de saúde em função das demandas sociais de nossa época.

Os que acreditam nas utopias sabem que elas são reạlizáveis, porque têm compromisso com o tempo, são eutópicas, estão presentes. Embora temporalmente defasadas, têm objetivos e metas, procuram o futuro partindo do presente, sem negar o passado. Não importam os descaminhos, os retrocessos, as distopias. As utopias continuam a marçar os caminhos da imaginação criadora. Elas estão seguras do amanhã, porque rompendo com as topias do presente, projetamse para o futuro, distinguindo-se, assim, das ideologias.

Embora a hegemonia dos serviços, no sistema integrado, seja reconhecida, cabe aos órgãos formadores de recursos humanos papel muito particular e relevante. Enquanto os servicos representam a realidade concreta à qual se deve ajustar o modelo educacional, cabe à Úniversidade o exercício permanente das utopias transformadoras. De fato, (. . .) a tradição deve ser ensinada, não para ser reproduzida, mas para ser transformada".
Frederico Simōes Barbosa Assessor da Secretaria da Educacão Superior Ministerio da Educapăo e Cultura 